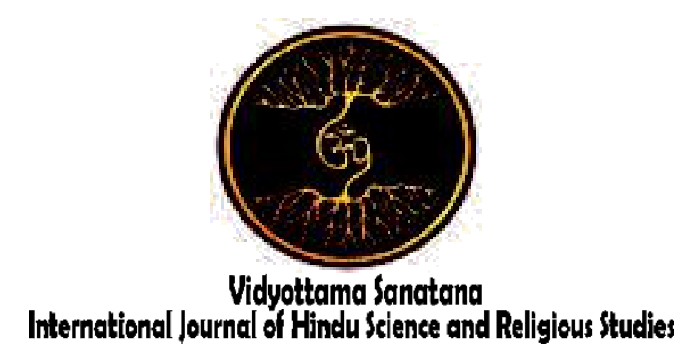

Vol. V No. 1 June 2021

\title{
THE CONCEPT OF VALUE IN RELIGIOUS PLURALITY IN INDONESIA (REFLECTION ON VERSES OF $\bar{I} S \bar{A}$ UPANIȘAD)
}

\author{
By: \\ Puspo Renan Joyo ${ }^{1}$, Septiana Dwiputri Maharani² \\ Universitas Gadjah Mada, Yogyakarta \\ Email: ${ }^{1}$ puspo.renan.joyo@mail.ugm.ac.id, ${ }^{2}$ septiana.dm@ugm.ac.id
}

Received: December 23, 2020 Accepted: June 08, $2021 \quad$ Published: June 30, 2021

\begin{abstract}
Indonesia is a pluralistic country. This plurality is indicated by the existence of ethnicities, races, customs, languages, and religions. Plurality does not only breed cooperation, but also conflict. The fact shows that religious plurality is one of the biggest challenges in Indonesia. This study aimed to explore the concept of value in the İsā Upanișad verses which correlate with the plurality of religions in Indonesia. This research used a qualitative approach. Data collection in this study was carried out through document studies on primary and secondary data sources. The primary data sources in this study are İsā Upanișad by Sri Aurobinda, The Principal Upanishads by S. Radhakrishnan, and The Upanisads: A Complete Guide by Cohen Signe, while secondary data sources include documents relevant to the object of the research material. The data analysis in this study used methodical steps of descriptive, interpretative, and holistic analysis, while the theory used is Gadamer's philosophical hermeneutic theory. The results of this study indicate that the verses in the Íśa Upanișad have a concept of value that is correlated with the plurality of religions in Indonesia: kinship, tolerance, and harmony; divinity, holiness, and glory; equality, justice, and non-discrimination; unity and oneness; brotherhood, empathy, love, and mutual respect.
\end{abstract}

Keywords: Upaniṣad, Ísaā Upanisad, Value 


\section{INTRODUCTION}

Indonesia is a big country. This fact is marked by the large area of Indonesia, the population, and the social condition of the community, which consists of diversity of ethnicities, races, religions, and languages. As the largest archipelago in the world, Indonesia has 17,499 islands from Sabang to Merauke. The total area of Indonesia is 7.81 million $\mathrm{km}^{2}$ consisting of 2.01 million $\mathrm{km}^{2}$ of land, 3.25 million $\mathrm{km}^{2}$ of sea, and 2.55 million $\mathrm{km}^{2}$ of the Exclusive Economic Zone. Indonesia is a country with an area of water greater than the land, therefore Indonesia is called a maritime country (Roza, 2017). From its social aspect, Indonesia is a country with a population of $237,641,326$ people, six religions and beliefs, 1,340 ethnic groups, and 2,500 languages (Na'im \& Syaputra, 2011). The society is composed of many social elements or structures that live side by side, but are not mixed up and still have their respective characteristics. Sociologically, Indonesian society is plural (Furnivall, 2010).

This plurality is woven into the bonds of the Indonesian nation as a united and sovereign nation. Apart from being based on the same socio-cultural, geographic, and historical background, the unity of Indonesia is also based on the unity of views, ideologies, and philosophies of life in one nation and state. The views, ideologies, and philosophies of life of the Indonesian nation are holistically reflected in the Pancasila principles, which are the basis of the Indonesian country. Meanwhile, the unity of views, ideologies, and philosophies of life of the Indonesian people is explicitly stated in the state symbol, written as Bhineka Tunggal $I k a$, which means various (in terms of ethnicity, religion, and language) but still one, Indonesia. The diversity of the Indonesian nation is one of the riches that are rarely owned by other countries in the world. Each of the Indonesian ethnic groups has their own unique customs and cultures. Indonesia's pluralism is destiny. Joko Widodo, the 7th President. said that Indonesia's pluralism is a reality that has been completed. Diversity has been resolved because it has become the agreement of the founders of the nation (Kawangung, 2019).

Recognizing the existing plurality, the founders of the Indonesian nation placed an important order as the basis for the state which was final and has officially become part of the history of Indonesian constitutionality and is firmly embedded as a recognized constitutional convention. The state foundation in question is Pancasila and the 1945 Constitution of the Republic of Indonesia (Asshiddiqie, 2011), as the constitutional basis for running the wheels of government and a mandate to protect and guarantee the rights of citizens.

Indonesia's plurality on the one hand is a tremendous gift from God. This reality gives us an important lesson that life always displays the face of diversity, and that we have to understand and accept this as the law of life (Joyo, 2020). But on the other hand, the encounter of values guided by each identity does not always present a dialogical and harmonious atmosphere; they also bring conflict. Diversity in another reality is a big challenge that has the potential to damage the beauty and peace of Indonesia if not cared for well and properly (Anwar \& Haq, 2019).

Currently, Indonesia's plurality is in big challenge. Of the many challenges that exist, one of the very serious ones is the plurality of religions. In the context of democracy, religion in Indonesia is currently facing dire challenges. There are at least two challenges faced by religions related to the conception of democracy. The first is the problem of understanding religious teachings and the second is the politicization of religion (Zainuddin, 2015). Various research studies have noted that the conflict between religions that occur show that the plurality of religions in Indonesia is not doing well (Haryanto, 2020; Muhtar, 2019; Susanto, 2017).

This situation seems ironic because religions that believe in being a source of goodness get stigma as a cause of religious conflict. Seeing this fact, Juergensmeyer stated that religion has provided not only ideology, but also motivation, justification, organizational structure, and its world view for perpetrators of violent acts. This has made religious symbols darker and more mysterious. Quoting the views of Emile 
Durkheim, Marcel Mauss, and Sigmund Freud, Juergensmeyer stated that religion looks like it needs violence and appears as a religion of violence (Juergensmeyer, 2017). This situation was exacerbated by the emergence of militant piety popularly called 'fundamentalism' in every major religious tradition in the late twentieth century. In fact, fundamentalism has suffered many defeats, but it is by no means silent. Today, fundamentalism has become an essential part of the modern panorama and will play an important role in domestic and international affairs in the future (Armstrong, 2011).

Based on the existing facts, efforts from various parties are needed to solve this problem. This paper is intended as an effort to explore the values in the verses of the İśa Upanișad which are related to religious plurality. This study is intended to contribute ideas and academic references related to the discourse of harmony and pluralism in Indonesia from the perspective of the İsā Upanișad book and Hinduism in general.

Several studies have been found discussing the themes adjacent to this paper. The first paper is a research conducted by Adnyana, et al., entitled "The Concept of Hindu God in İsā Upanișad (Hindu Theological Studies)," published in the Journal of Religious Research Hinduism, Volume 2 Number 1, 2018. Adnyana's research describes the main teachings and theology of Hinduism including İsā as an absolute and impersonal essence, teachings of karma, the cosmos, and on VidyāAvidyā (Adnyana et al., 2018). The second is a research entitled "Brahma Vidyā in the Book İsā Upaniṣad (Study of Hindu Theology)" by Adnyana, published in Pangkaja Journal Volume 22 Number 1, 2019 (Adnyana, 2019). If the two studies above focus on the study of Hindu theology, this study focuses on the disclosure of the plurality values contained in the İsāa Upanișad.

\section{METHOD}

This study used a qualitative approach with concepts of value in the İsā Upanișad as material object (Ratna, 2009). Data collection in this study was carried out through document studies on primary and secondary data sources. The primary data sources in this study are Iśā Upanișad by Sri Aurobinda, The Principal Upanishads: Edited with Introduction, Text, Translation and Notes by S. Radhakrishnan, and The Upanisads: A Complete Guide by Cohen Signe, while secondary data sources include documents relevant to the object of research material (Bungin, 2007). Data analysis in this study used methodical steps of descriptive, interpretative, and holistic analysis (Bakker \& Zubair, 1990). The theory used in this research is Hans-Georg Gadamer's Philosophical Hermeneutics theory (Bertens, 2019; Hardiman, 2015).

\section{RESULTS AND DISCUSSION}

\subsection{The Upanișad}

Hindu scriptures are very broad. Their significances are sorted differently according to the particular point of view of an individual. In Hinduism, there are six darshana, or philosophical systems. They sometimes provide explanations that seem to differ from one another, but people with wisdom understand that this is due to their different ways of seeing the same thing. That fact is what makes them both valid and ultimately harmonious. That unifying subject is Brahman, the Absolute God. All followers of the Sanatana Dharma agree that the Veda is the supreme authority, and the Veda has always been understood to include treatises on mystical and speculative philosophy known as the Upanișad (Giri, 2013).

The Upanișad comes from Upa (near), ni (below), sad (sitting); means 'sitting down near'. A group of sișya (disciples) sit near the Ācārya (teachers) to study Upanișad teachings, examine their most essential matters, and present them to nearby sișya. The Ācārya took a stance of being quiet in conveying the truth. He hopes that his sisyya are spiritually minded and not worldly, because to get the result of spiritual study requires a spiritual nature as well. The Upanișad are part of the Vedic scriptures which are the final part of the Veda (Mantra). In view of their position as the latter part (anta), the Upanișad is called the Vedānta. In the Vedic codification, the Upanișad 
is part of Śruti (revelation).

According to its content, Vedānta is divided into two, namely Karma Kāṇa (containing the main provisions regarding rituals), and Jñāna Kānḍa (containing the teachings of Divinity). Karma Kanḍa is more commonly known as the Brāhmaṇa or the Brāhmaṇa Books. Brāhmaṇa means prayer. Each of the Veda has a book of Brāhmaṇa. The Brāhmaṇa Books are seven in number, namely: Aitareya Brāhmaṇa, Kauṣītaki Brāhmaṇa, Tāṇụa Brāhmaṇa, Sadvimśa Brāhmaṇa, Taittirīya Brāhmaṇa, Śatapatha Brāhmaṇa and Gopatha Brāhmaṇa. The Aitareya and the Kauṣitaki Brāhmaña are part of the Rg.Veda. The Tāndya and the Sadvimśa Brāhmana are part of the Sāma Veda. The Taittirīya and Śatapatha Brāhmaṇa are part of the Yajur Veda, while the Gopatha Brāhmana is part of the Atharva Veda (S. Radhakrishnan, 1994).

The Brāhmana Books are the second part of the Veda which contain instructions on rituals. The third part of the Veda, which is also considered to be the final part of the Veda, is the Upanișad. This book is called the Rahasya Jñāna, because it contains an explanation of the teachings or knowledge of Divinity (Brahma Vidyā), which is an important foundation of Hindu life. This Upanișad is eternal, sanātana. Its truths are said to be brought out of the breath of God or are visions of the saints. The Upanișad actually represents an important chapter in human spiritual history and have influenced philosophy, religion, and the lives of people for thousands of years. In the east, the religious movement showed itself in line with the assertion of the Upanișad philosophy.

Research on various part of Upanișad has long been carried out by Indology scholars both in India and in the West. From the existing research, it was found that no less than 108 Upanișad were found. Thirteen of them are considered to be the oldest Upanișad, namely: Chāndogya, Bṛhadāraṇyaka, Aitareya, taittirīya, Kaṭha, İsaā, Muṇụaka, Kauṣītaki, Kena, Praśna, Śvetāśvatara, Māṇūūkya, and Maitri Upanișad. Regarding the teaching period of the Upanișad, according to the estimates of the Indology scholars as stated by $\mathrm{S}$.
Radhakrishnan, it is not certain, but it can be confirmed that the Upanișad was composed long before the time of Buddha Siddharta. This means that the Upanișad has existed at least in the 6th century $\mathrm{BC}$ and was composed between X BC III BC (1000 BC-300 BC). Age determination of the youngest Upanișad, in the 3rd century BC, after the Buddha's era based on the age of the Upanisad books, was discussed by the Sankarācārya. Thus, it can be argued that the age of the Upanișad is commensurable with the age of the Dharmaśāstra. The time span of the Upanișad creation which covered hundreds of years is found based on the number of Upanișad. It has also been stated that Upanișad books were not written in one era (Radhakrishnan, 1957).

\section{2. İsā Upaniṣad}

Íśā Upanișad is part of the Upanișad. İśā Upanișad is also known by the name İ́avasya Upanisad. İśā (İś) means the Soul of the entire universe. This title is given because in that sense we find an explanation that this universe is a creation and is lived by İśā (God). Therefore, He as the Soul-giver, is the Supreme Soul called Iśā (Aurobindo, 2003).

This Upanișad is the shortest and smallest of the Upanișad, but is the most important of all the Upanișad. İsā Upanișad consists of only eighteen śloka (verses). According to its origins, İsā Upanișad is part of Śruti, namely the Sukla Yajur Veda. This is because the İsā Upanișad is one of the chapters (Adhyāya) of the Yajur Veda, namely the 40th Adhyāya. Sukla Yajur Veda is known as Vājasaneyi or Vājasaneyi Samhitā. Vājasaneyi is the title of a Maha Rși who compiled the Yajur Veda Samhitā mantras. Therefore, the İsaa Upanișad is also known as the Vājasaneyi Samhitā Upanișad or simply called the Vãjasaneyi Upanișad. Seeing the position of the İsā Upanișad in the Yajur Veda, it means that the Íśa Upanișad is Śruti. The Yajur Veda is one of the Vedic Chess (RgVeda, Sāma Veda, Yajur Veda, and Atharwa Veda) (Pudja, 1999).

Looking at the content, the Íśa Upanișad teaches about the main points of understanding about Ísan, but systematically the brief content consists of several teachings that form the basis of Hindu knowledge. The knowledge conveyed is as follows. 
First, knowledge which teaches that the universe is outwardly multifarious but all of them have one source, they are all creations under the power of God (İśā). Second, the knowledge that teaches about detachment from acting (Karma Vairāgya) because attachment will be a barrier to reaching the highest goal. Third, knowledge that explains the paradoxical nature or the multiplicity of the nature of the universe. The absolute is one seen in relative terms. Four, knowledge of the nature of God as the ruler of the universe. Five, knowledge of Asambhūti (relative trait) and Sambhūti (absolute trait) (Cohen, 2018).

\subsection{Values in the İsã Upaniṣad Verses}

3.3.1. We are in the Same House (Concept of the Value of Kinship, Tolerance, and Harmony)

Before entering into a discussion of the theme in this section, we will first convey verse I of İsāa Upaniṣad as a reflection.

"Íśâvāsyam idam sarvam yat kim ca jagatyām jagat, tena tyaktena bhuñjīh $\bar{a}, m \bar{a}$ grdhah kasyasvid dhanam."

(Know That) all this, whatever moves in this moving world, is enveloped by God. Therefore, find your enjoyment in renunciation, do not covet what belongs to others.

(S. Radhakrishnan, 1994).

To enter the mystical atmosphere in this verse and explore the meaning of this noble message, a story will be told. In ancient India, there lived the wisest Brahmin who was considered by everyone to be the best philosopher. One day, the local king asked the Brahmin to kindly come to the palace. According to the King's request, the Brahmin came and met him at the palace. Seeing the Brahmin's arrival, the king approached and invited him to sit in the main hall of the palace. At that time, the King said, "O Brahmin, I have three questions that have puzzled, even tormented me all this time. These are my three questions. First, where is God? Second, why don't I see Him? And third, what is God doing all day long? You are known as the wisest and most learned Brahmin, so if you cannot answer these three questions, I will punish you!' Hearing the King's words, the Brahmin was shocked and terrified because the answers to these questions were not only complicated but also impossible to define. In other words, the Brahmin did not know the answer. Since the Brahmin did not give up and was unable to give any answers to the King, a date for his punishment was set.

In the morning of that day, a boy who was still a teenager, the son of the Brahmin, appeared and asked the king, "Would you release my father if I could answer those questions?" Hearing that question, the King agreed. The boy then asked for a container of milk to be brought to him. He then asked for the milk to be stirred until it became butter. What the boy asked for was done.

"Your first two questions have now been answered," he said to the King.

The King objected because he felt that he had not been given any answers.

Then the Brahmin's son asked, "Where was the butter before being stirred?"

"In the milk," answered the King.

"Where's the milk?" asked the boy.

"In all of it," said the King.

"That's it. God is in all things and pervades all things in the same way," the boy replied.

"Why don't I see Him?" insisted the King.

"Because you don't 'stir up' your mind and improve your perception through meditation. If you do that, you will see God. But not the other way around. Now let my father go," begged the boy.

"Not now," replied the King. "You haven't told me what God is doing all day."

"To answer that," said the boy, "we have to exchange our positions. You come stand here and let me sit on the throne," said the boy.

The request was so bold that the King complied, and a moment later, he stood before the Brahmin's boy sitting on the throne. The son of the Brahmin gave him the answer.

"This is the answer. One time you were here and I was there. Now everything is upside down. God is always lifting and dropping all of us. In one life, we are exalted and in another, we are humbled. Often times in one lifetime, this happens, and even more than once. Our life is completely in His hands, and He does as $\mathrm{He}$ 
pleases. God lowers the mighty from their seats, and raise up those who are humble." (Giri, 2013).

Hearing the boy's answer, the King felt that he had found the answer he had been looking for. The King was satisfied and the Brahmin was released, and the son of the Brahmin was given many rewards and gifts by the king.

Iśā Upanișad opens with answers to questions about God's 'being'. What has been stated in the verse I of Îśa Upanișad above and the story of a Brahmin and the King provides an important insight into 'perception'. We are accustomed to ideas or knowledge that are based on what we perceive through experience or senses. It is interesting to investigate further about 'perception', because the explanation has to do with the philosophical intent of the İsāa Upanișad regarding the way of seeing things.

Talking about 'perception', it is considered important to listen to the debate between two great philosophers, John Locke and George Berkeley. In their dialogue of 'perception', Locke rejected the notion that 'what is understood' was superior to 'what is felt'. On the contrary, he emphasized that all intelligence was drawn from the senses. Interestingly, he compared human intellect at birth with 'Tabula Rasa', which is an unwritten board. In this way, he wanted to not only get rid of any 'innate ideas', but also to prepare an explanation of how meaning was structured by the hard work of sensory data. Humans did not know anything that was not withdrawn from the senses. The only original writing on the human mind/intelligence board was the one written by the senses. In this context, Locke is an empiricist (sensory empiricist), that is a person who maintains that the entire contents of the mind can eventually be reduced to sensory experience. According to Locke, what we know are 'ideas'. Generally, people claim that they are aware of things. But, according to Locke, the object of consciousness is an idea. Ideas are "objects of reason when people think; I have used it to express whatever is meant by phantasm, meaning, species, or whatever is used by mind/intelligence to think". He also said that ideas are "the direct object of perception."

Responding to Locke's view, while what is identified as 'being' is what is perceived, it means things that are not perceived do not exist. Berkeley then asked, does this mean that if I left this room, the perceived objects that fill it ceased to exist? The answer is no, because these objects can be perceived by certain other minds/intelligence. Berkeley did not say that individual mind/intelligence gives reality to things. But what if there was no one there? Berkeley still said that things exist. To him, it is not only a possibility, but an absolute mind/intelligence (God) who perceives the data that we perceive every time. If there was no limited mind perceiving their mind/intelligence, they could still be said to exist (Gallagher, 1994).

From the story of a Brahmin and the King, continued by scrutinizing the debate between Locke and Berkeley, presumably, it can be understood that we are accustomed to seeing truths based on what we perceive. Absolute truth is reduced to such a degree according to what is perceived by the senses, and vice versa, something unperceivable by the senses is not in our ideas. This was as explained by Locke with his theory. Berkeley said something interesting regarding a question: if there was no one perceiving an object, does the object ceased to exist? Berkeley answered by stating that the object would still exist, because there is an absolute intellect (God) who perceives it to make it exist. The presence of 'Absolute Intelligence' seems to have opened up a possibility of truth and a new way of seeing things (truth). It is as also conveyed in the story between the Brahmin and the King when the Son of the Brahmin asked to stir the milk until it became butter, and then he asked again where the milk was.

These stories are interesting in connection with the verse I of İsā Upanișad which states

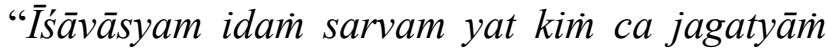
jagat," that "this whole being (jagat) is enveloped by İsā (God)." Of course, in our perception, this sounds ridiculous because our perception does not see that reality. But on the contrary, our perceptions provide information that we are different beings from one another. We are different in every way, in matters of belief 
(religion), customs, culture, race, color, language, country, continent, and so on. We are used to direct perception that presents a million differences and we do not have enough time to observe and explore the differences that we perceive. The differences that are grown and nurtured since birth have provided a considerable distance between us psychologically. In our perception, each individual really has become 'the other' in everything. Our perception is not familiar with union, but it is with separation and difference.

What is conveyed in the verse I of Iśa Upanișad is an implicit understanding of the other side of 'perception'. In response to this śloka, "Íśāvāsyam idam sarvam yat kim ca jagatyām jagat," meaning that "this whole being (jagat) is enveloped by Iśā (God)." Radhakrishnan declared that the world is not independent without God, but is pervaded by Him. All moving and changing objects derive their use from their association with the singular truth (İsāa) (S. Radhakrishnan, 1994). Sri Aurobindo gave an important meaning regarding this matter. He stated that the first thing that must be put in the basis of our thinking is the existence of a stable spirit (İśā) that inhabits and regulates the motion of the universe and its forms of movement (Aurobindo, 2003).

The İsāa Upanișad in this verse has both provided insight and awakened our awareness that the 'perception' which displays so many differences separating one from another are actually in one space, the universe, jagat. All existing differences are bound up in the same space, in the same sphere, and from the same source, İsā. The spirit which 'equates' and 'unifies' is unable to be perceived by our senses, but that does not mean it does not exist. This is me with the story of the Brahmin's son in the previous story asking about the presence of milk in butter. This is also what Berkeley meant when arguing with Locke about 'ideas' which are as a whole perceived from sensory perception, and did not acknowledge the reverse situation, including 'innate ideas.'

What has been said by the İsā Upaniṣad seems to want to put a transformative idea and a paradigm construction from 'particular' to 'universal' and from 'exoteric' to 'esoteric'. This paradigm transformation has implications for our perception which initially tends to focus on things that are specific, micro, particular, and attached to differences, leading to a model of perception that is holistic, macro, universal, and singular. Through this holistic paradigm model, it is possible for us to have a deeper and more complete understanding of exoteric phenomena which are full of differences. Thus, we no longer feel like 'the other' and are in different houses. Instead, we are a family in the same house. Plato stated in Phaedo that what is invisible seems always the same, but what is visible is never the same (Hackforth, 1972; Young, 2020).

\subsubsection{God is among us (Concept of the Value of Divinity, Holiness, and Glory)}

Swami Nirmalananda Giri gave two important meanings to the verse I of İsā Upaniṣad, "İśāvāsyam idam sarvam yat kim ca jagatyām jagat, tena tyaktena bhuñjīhā, mā grdhah kasyasvid dhanam." He stated that, first, we must experience and not just think intellectually. God includes all things, that we should not see everything as independent or separated from God, but this 'being' is in God. This vision must extend to us. We are also within İ́ā (God). Second, in seeing all things (everything), God must be between us and the all things. Therefore, we must see God first, and only then see all these things (Giri, 2013).

Having previously realized that "we are actually in the same house," then Swami Nirmalananda Giri's idea provides an important lesson about our perception of people, a significant perceptual progression from the particular to the universal paradigm. That is, if previously we were accustomed to perceptions that tended to be specific, then implicitly Swami Nirmalananda Giri offered the opposite: building a holistic perception. This perception does not automatically negate particular things. The particular things are there and they are real, but not an end point. In the perspective of perennialism, plurality exists in exoteric space. Whereas in another space, esoteric, plurality is seen and its historicity is traced to look for common ground towards transcendental unity 
(Amallia, 2019; Huxley, 1945). In this context, the unity is in the sense of 'Íśà', God who houses the 'Jagat', a space of life that binds all existing plurality.

Understanding the equality of space (jagat) is important for our perception of others. In the way we see things, God must be positioned between us and everything. We have to see God first. There is no empty space without the presence of God among us, all filled with İsā. Referring to İsāa Upanișad 8, it is said as follows.

"sa paryagāc chukram akāyam avraṇam kavir man̄̄și paribhūh svayambhūr yāthātathayato 'rthān vyadadhāc chāśvatībhyah samābhyah."

(He has filled all; He is radiant, bodiless, invulnerable, devoid of sinews, pure, untouched by evil. He, the seer, thinker, allpervading, self-existent has duly distributed through endless years the objects according to their natures.)

(S. Radhakrishnan, 1994).

The word 'paribhūh' in the above verse means Íśā (God) is everywhere. God is present in all space and time. There is no empty place without Him. This shows the nature of God Almighty, because He also controls space and time, and vice versa. The Chāndogya Upanișad, III.14.I, states, "Sarvam khalv idam brahma", meaning that in fact, the whole world is Brahman. Likewise, in the Maitri Upanișad, IV.6, it is stated, "Brahma khalv idam vāva sarvam," that is, Brahman is the preceding of these and the one who produces these things (S. Radhakrishnan, 1994).

This description of the Upanișad verse confirms the existence of İsā (God) in this immense universe. The denial of God's presence among us is a shameless form of arrogance and a sign of the absence of knowledge (avidya). This universe is a spiritual home to shelter and work for all of God's creations. At the same time, all inhabitants of this universe (Jagat) receive equal respect and treatment by God. As revealed in the Bhagavadgita, this life is a 'dharma field' (dharma-kșetre) where people strive to improve life through their actions, a place of moral struggle to determine what is right (dharma) (Mantik, 2007; Miller, 1998; Yogananda, 2007). The world is a vehicle for the transformation of sentient beings, the momentum of selfpurification from forgetfulness to consciousness, from ugliness to virtue, as stated in the Sarasamuccaya 2 "mānusah sarvabhūteșu varttate vai șubhāśubhe, aśubheșu samaviștam śubhesvevāvakārayet"(Kadjeng, 1999).

\subsubsection{God is the Owner, Not Us (Concept of} the Value of Equality, Justice, and Nondiscrimination)

God as the ruler and owner of the universe (jagat) has been written in İsā Upanișad I, "Íśâvāsyam idam sarvam yat kim ca jagatyām the jagat, tena tyaktena bhuñjīha, mā grdhah kasyasvid dhanam" Referring to the word 'Íśa $v \bar{a}$ syam' in this verse, Radhakrishnan provides an explanation that in essence, the world does not stand alone without God. The earth and all of it (jagat) belongs to God. İsā in this case is seen as the cosmic ruler. A similar explanation was also delivered by İsāā Upaniṣad 8 , "sa paryagāe chukram akāyam avraṇam kavir manīṣī paribhūh svayambhūr yāthātathayato 'rthān vyadadhāc chāśvatībhyah samābhyah." The word 'svayambhüh' in this verse means 'to exist by itself' (self-existent). According to Cohen, this word shows that İsā (God) is the original source of all creation, which only exists by its own power and not through the creation of others. God made all of creation exist (Cohen, 2018).

If we understand and accept what the Upanișad have said above, then we can take a step forward and experience that "Íśa is the true owner." We can conclude that our ego about ownership is really an illusion. The great nondualist philosopher Shankara explained an accurate view of this example by likening our experience to seeing a rope in the dim light and mistaking it for a snake. Our mind even gives us sparkling eyes and sizzling mouth to the rope. But when illuminated by the light, it turns out that what we think of as snake is only a rope. The snake is not real, but the impression, however wrong it is, is real. The snake is not real, does not exist; but the impression of a snake is real and it does exist. The rope is reality and the snake is an illusion overlapping on it. In the same way, God 
is reality, as well as the reality of the true owner. Everything else is an illusion like a snake. However, illusions do exist. Denying it gets us nowhere; we have to face it by seeing it, by removing it. Only then, we will see the reality (Giri, 2013).

A book entitled How to Enjoy Your Life and Your Job by Dale Carnegie tells a telephone company in New York. Carnegie once conducted a study on conversations conducted by people on the telephone. They wanted to know what words were used the most. The results showed that in 5,000 telephone conversations, there were 3,990 'I' words. Still within the same source, John Dewey once said that the desire to be considered important is a hidden desire in humans, while Willian James said, "The desire that humans crave the most is the desire to be respected." (Carnegie, 2020).

Thomas Hobbes once stated that humans are an anti-social machine. All human action involves combining reason and desire in the form of lust and aversion. Desire gives the goal of human action, reason imitates the means to that end, which Hobbes calls 'power'. Therefore, human life is an everlasting desire that never goes out to gain more and more power and only stops when death comes (Campbell, 1981).

What were conveyed by Carnegie and Hobbes show that humans are creatures that are very self-oriented. Humans are a complicated combination of ego and desire. Aurobindo said that the desire to own and enjoy things is the main impetus of the Ego which gives birth to clashes with others and oneself, mental and physical suffering, feelings of weakness and inadequacy, confusion, lust and desire for selffulfillment, disappointment, and destruction (Aurobindo, 2003).

The understanding of 'ownership' is important because it has implications for perceptions between individuals. Intelligence, wealth, knowledge, piety, beauty, popularity, class, race, religion, nation, and other identities that are inherent in humans often unconsciously lead humans to ego and pride. Thus, in his perception, he no longer sees other individuals on an equal level. This situation then raises the claims of certain individuals, groups, and identities who feel better than others. This is where discrimination begins.

\subsubsection{Transcending Duality (The Concept of}

the Value of Unity and Oneness)

"anejad ekam manaso javīyo nainad devā āpnuvan pūrvamarșat, tad dhāvato'nyānatyeti tișthat tasminn apo mātariśvā dadhāti."

('The Spirit' is unmoving, one, swifter than the mind. The senses do not reach It as It is ever ahead of them though Itself standing still. It outstrips those who run in It. The allpervading air supports the activities of beings.)

"tad ejati tan naijati tad dūre tad vad antike, tad antarasya sarvasya tad u sarvasyāsya bāhyatah."

(It moves and It moves nit; It is far and It is near; It is within all this and It is also outside all this).

(S. Radhakrishnan, 1994).

In verses 4 and 5 of İsã Upanișad, God is explained by means of a series of paradoxes: $\mathrm{He}$ does not move, but is faster than the mind and faster than those who run, he is far and near, he is inside and outside. He (eka) transcends all dualities, such as wisdom and ignorance, existence and non-existence, creation and dissolution. According to Radhakrishnan, this contradictory statement is not a sign of the author's imbalance. This is a description of his experiences through the limitations of human thought and language. The Absolute is beyond the reach of human thoughts. Thought is a symbol and therefore cannot describe the Absolute apart from denial (not this, not that). But the Absolute is not emptiness. He exists at any time but $\mathrm{He}$ is also outside of time. He is distant because $\mathrm{He}$ is impossible to reach for those who do not understand and He is very near to those who do, for $\mathrm{He}$ is actually his own 'ātman' (S. Radhakrishnan, 1994).

What are stated in the above verses tell us that not only God himself transcends duality, but humans who seek immortality must learn on their own to move beyond dualistic perceptions of the world. Operationally, this perception is able to capture the singularity in the plurality of human identities. Thus, the perception does not stop at an 
exoteric level which tends to identify differences, but on the contrary, moves towards esoteric spaces and sees the essence of oneness in its transcendent dimension. The idea that ultimate truth is beyond all dualistic constructs of reality has ancient roots in Vedic thought. Singular and Plural, both are the aspects of God. Singularity is the truth and plurality is the manifestation. Singularity is the basis of plurality and supports it, but plurality does not create and support the singular.

\subsubsection{You and I are One (Concepts of the} Value of Brotherhood, Empathy, Love, and Mutual Respect)

In Alcibiades, Socrates said that he who commands "Know thyself" orders us in to "Know our Soul", and he who only understands his body "Knowing only those things which he has but not himself" (Ellis, 2014). What Socrates said about 'self' goes beyond the general understanding that identifies oneself as 'body'. This is in line with Upanișhadic thought, which sees the 'self' as transcending physical boundaries. The 'sel' is identified as 'ātman'. Verse 6 of İsā Upaniṣad states as follows.

"yas tu sarvāṇi bhūtāni àtmany evānupaśyati, sarvabhūteșu cātmānam tato na vijugupsate."

(and he who sees all beings in his own self and his own self in all beings, he does not feel any revulsion by reason of such a view).

In response to this verse, Radhakrishnan stated that the verse describes the transformation of the Soul, the absorption of God which is located in the entire universe (jagat). It also explains how unity also forms the basis of plurality and underpins plurality. Therefore, the essence of the Absolute is simple attman. Plurality is His creation. Brahman is the attman of all and all of this is a manifestation of the One (S. Radhakrishnan, 1994).

According to Cohen, the Íśā Upanișad clearly expresses the idea that all individual selves are ultimately one. When one sees all beings in ātman, and âtman in all beings, it does not hide itself. When someone who is knowledgeable in his ātman becomes all beings, what confusion or sadness might there be for one who has seen oneness? The İsā Upanișad states that the 'God' which pervades the whole world is identical to the ātman that is within. The idea that divine beings are immanent in the universe and in men provides an ethical imperative because the divine presence in every creature leads to reverence for all life (Cohen, 2018).

Chāndogya The Upaniṣad VI.8.7 also describes the oneness in ātman as follows.

"sa ya eso 'nimā aitad àtmyam sarvam, tat satyam, sa àtmā: tat tvam asi, svetaketo, iti: bhūya ena mā, bhagavān, vijñāpayatv iti, tathā, saumya, iti hovāca."

(That which is the subtle essence (the root of all) this whole world has for itself. That is the truth. That is the self. That art thou, Śvetaketu, 'Please, be Venerable Sir, instruct me still further'. 'So be it, my dear ', said he).

"tat tvam asi" means it is you. This famous expression emphasizes the divine side of the human soul. He who only understands what is in the body and mind only understands what is possible to be his and does not understand himself. The expression "you are I" is applied to the being within, antah purusa, and not to the empirical soul with his name and descendants. Aurobindo stated that İsā, that is the same God who resides in numbers and parts, is in the cosmos as a whole and in every being, force, or object in the cosmos. Because $\mathrm{He}$ is one and inseparable, the Soul in all is one, and its diversity is a game of His cosmic consciousness. Therefore, every human being is essential for one and another (Aurobindo, 2003).

\section{CONCLUSION}

Based on the research, it can be concluded that the explanation in the verses of İsā Upanișad contain the concept of religious plurality, as follows.

First, the study of the verse I of İsā Upanișad describes three important things, namely: 1) İsā Upanișad, explaining that the entire world created by Ísá (God) is actually in the same house, the universe (jagat). From this understanding, the concepts of the value of kinship, tolerance, and harmony are born; 2) İśā Upaniṣad, philosophically describing the existence of İsā 
(God) and His creation. The whole universe is covered by Íśā (God), therefore Iśā (God) is among His creation. From here, the concepts of the value of divinity, holiness, and glory arise; 3) İsaa Upaniṣad, describing 'the Owner' as İsā (God). The meaning of 'the owner' other than İsā (Lord) is a wrong perception. This explanation contains the concepts of the value of equality, justice, and non-discrimination).

Second, verses 4 and 5 of İsā Upanișad describe God through a series of paradoxes. This tells us that not only does God himself transcends duality, but men seeking immortality must learn on their own to move beyond dualistic perception of the world. What is described here gives rise to the concepts of the value of unity and oneness.

Third, verse 6 of İsã Upaniṣad describes that all individual selves are ultimately one, that is, one unity within ātman. He who only understands what is in the body and mind actually does not know himself. The ability to identify others in themselves is the fruit of this understanding. This Ísāa Upaniṣad thought gives rise to the concepts of the value of brotherhood, empathy, love, and mutual respect).

\section{REFERENCE}

Adnyana, P. E. S. (2019). Brahma Vidyā dalam Kitab Î́saa Upaniṣad (Studi Teologi Hindu). JURNAL PANGKAJA : JURNAL AGAMA HINDHU, Volume 22, 44-54.

Adnyana, P. E. S., Dwitayasa, I. M., \& Brahman, I. M. A. (2018). Konsep Ketuhanan Hindu dalam İśā Upanișad (Kajian Teologi Hindu). Jurnal Penelitian Agama Hindu, 2(1), 439. https://doi.org/10.25078/jpah.v2i1.501

Amallia, S. (2019). Hakekat Agama Dalam Perspektif Filsafat Perenial. Indonesian Journal of Islamic Theology and Philosophy, $1(1)$. https://doi.org/10.24042/ijitp.v1i1.3903

Anwar, F., \& Haq, I. (2019). Religious Moderation Campaign Through Social Media at Multicultural Communities. KURIOSITAS: Media Komunikasi Sosial Dan Keagamaan, 12(2), 177-187. https://doi.org/10.35905/kur.v12i2.1392

Armstrong, K. (2011). The battle for God: A history offundamentalism. Ballantine Books.

Asshiddiqie, J. (2011). Membudayakan nilainilai pancasila dan Kaedah-kaedah Undangundang Dasar Negara RI tahun 1945. Kongres Pancasila III.

Aurobindo, S. (2003). Isha Upanishad. Sri Aurobinda Ashram Press.

Bakker, A., \& Zubair, A. C. (1990). Metodologi Penelitian Filsafat. Kanisius.

Bertens, K. (2019). Filsafat Barat Kontemporer Jilid I Inggris \& Jerman. PT. Gramedia Pustaka Utama.

Bungin, B. (2007). Penelitian Kualitatif: Komunikasi, Kebijakan Publik, dan Ilmu Sosial Lainnya. Prenada Media Group.

Campbell, T. (1981). Seven theories of human society. Clarendon Press.

Carnegie, D. (2020). How to enjoy your life and your job. Diamond Pocket Books (P) Ltd..

Cohen, S. (2018). The Upanisads A Complete Guide. Routledge.

Ellis, W. M. (2014). Alcibiades (Routledge Revivals). Routledge.

Furnivall, J. S. (2010). Netherlands India: A Study of Plural Economy. Cambridge University Press.

Gallagher, K. T. (1994). Epistemologi Filsafat Pengetahuan. Kanisius.

Giri, S. N. (2013). A Commentary on The Upanishads. Atma Jyoti Ashram.

Hackforth, R. (Ed. . (1972). Plato: Phaedo. Cambridge University Press.

Hardiman, F. B. (2015). Seni Memahami: Hermeneutik dari Schleiermacher sampai Derrida. Kanisius.

Haryanto, S. (2020). The sociological context of religion in Indonesia. Research in the Social Scientific Study of Religion, 30, 67-102. https://doi.org/10.1163/9789004416987_00 6

Huxley, A. (1945). The Perennial Philosophy. Harper and Brothers Publisher.

Joyo, P. R. (2020). Wacana Keragaman Eksoteris dan Kemanunggalan Transenden dalam Hinduisme (Tinjauan Filsafat Perennial). In I. K. Sudarsana (Ed.), Beragama dalam Damai (pp. 145-183). Jayapangus Press Books.

Juergensmeyer, M. (2017). Terror in the mind of God: The global rise of religious violence 
(Vol. 13). University of California Press.

Kadjeng, I. N. (1999). Sarasamuccaya. Paramita.

Kawangung, Y. (2019). Religious moderation discourse in plurality of social harmony in Indonesia. International Journal of Social Sciences and Humanities, 3(1), 160-170. https://doi.org/10.29332/ijssh.v3n1.277

Mantik, A. S. (2007). Bhagavadgita. Paramita.

Miller, R. (1998). BOOK REVIEWS: God Talks With Arjuna-The Bhagavad Gita: The Royal Science of God-Realization. Self-Realization Fellowship, 2 volumes Paramahansa Yogananda. International Journal of Yoga Therapy, 8(1), 55-62. https://doi.org/10.17761/ijyt.8.1.44252266 $276634 v 5$

Muhtar, F. (2019). The Resolution of Religious Controversy in Multicultural Society in Indonesia. Al-Tahrir: Jurnal Pemikiran Islam, 18(2), 395. https://doi.org/10.21154/altahrir.v18i2.13 81

Na'im, A., \& Syaputra, H. (2011). Kewarganegaraan, Suku Bangsa, Agama dan Bahasa Sehari-Hari Penduduk Indonesia (Hasil Sensus Penduduk 2010). Badan Pusat Statistik. https://media.neliti.com/media/publication s/49956-ID-kewarganegaraan-sukubangsa-agama-dan-bahasa-sehari-haripenduduk-indonesia.pdf

Pudja, G. (1999). Isa Upanisad. Paramita.

Radhakrishnan, S. (1957). Indian Philosophy . Princeton University Press.

Ratna, N. K. (2009). Penelitian Sastra: Teori, Metode dan Teknik. Pustaka Pelajar.

Roza, E. (2017). Maritim Indonesia, Kemewahan Yang Luar Biasa. Kementrian Kelautan Dan Perikanan Republik Indonesia, https://kkp.go.id/artikel/2233-maritimindonesia-kemewahan-yang-luar-biasa

S. Radhakrishnan. (1994). The Principal Upanishads: Edited with Introduction, Text, Translation and Notes By $S$. Radhakrishnan. Harper Collins.

Susanto, E. H. (2017). Conflict between Groups of Different Religion and Beliefs Posing as Threat to Heterogeneity in Indonesia. Modern Applied Science, 11(12), https://doi.org/10.5539/mas.v11n12p22

Yogananda, P. (2007). God talks with arjuna. Diamond Pocket Books (P) Ltd..

Young, D. (2020). Soul as Structure in Plato's Phaedo. Apeiron, 46(4). https://doi.org/10.1515/apeiron-2012-0018

Zainuddin, M. (2015). Plurality of religion: Future challenges of religion and democracy in Indonesia. Journal of Indonesian Islam, 9(2), 151-166. https://doi.org/10.15642/JIIS.2015.9.2.151166 